\title{
ORIGINALARTICLE
}

\section{Belt and Road Initiative (BRI): Enhancing ICT connectivity in China-Central Asia Corridor ${ }^{\dagger}$}

\author{
. XQDJRLQ. XQDXXW\$ WXNRI NXGD" RQJMQJY HH
}

United Nations Economic and Social Commission for Asia and the Pacific, Bangkok, Thailand

\begin{abstract}
The Belt and Road Initiative (BRI) aims to enhance connectivity and collaboration among 60 countries and beyond in Asia, Africa and Europe. Information and communications technology (ICT) is an indispensable component of the initiative, critical in providing fundamental communication channels for global financial transactions, trade exchanges and transport and energy connectivity, and socio cultural collaboration and scientific exchanges between people, organizations and countries along the BRI corridors. Previously constrained by infrastructure deficits in ICT, the Asia-Pacific region is accelerating its efforts to provide reliable and affordable broadband networks throughout the region, to contribute to successful implementation of the Sustainable Development Goals (SDG).

Within the BRI corridors, this study which has been undertaken as part of the research programme of the United Nations Economic and Social Commission for Asia and the Pacific (ESCAP) on pr omoting regional economic cooperation and integration, focuses on the China-Central Asia Corridor (China, Kazakhstan, Kyrgyzstan, Tajikistan, Turkmenistan and Uzbekistan), giving attention to the sub-region's specific challenges, namely limited international transit opportunities and an increase in bandwidth requirements that is expected to grow exponentially, as the fourth industrial evolution centered on automation and artificial intelligence gathers momentum. The sub-region is characterized as highly dependent on the ease and costs of connecting to neighboring countries for transit, as many countries in the sub-region are landlocked developing countries (LLDC). Because of the geographical features and other factors, the development potential of Central Asia and its integration into globalization, continues to be stymied by insufficient international bandwidth and high transit costs to access international links. Therefore, improved ICT connectivity in Central Asia through the BRI corridor could result in improved availability and affordability of broadband networks and services in the sub-region.

For the purpose of this study, a gap analysis is the methodology that underpins the proposed topology for the China-Central Asia Corridor. The analysis included examining the current state of the optic infrastructure, such as existing and planned fiber-optic networks, existing Internet Exchange Points (IXPs) and international gateways. The study also identifies the key factors that determine the desired future state

\footnotetext{
$\dagger$ An earlier version of this paper was published as an UNESCAP Working Paper titled, "A Study of ICT Connectivity for the Belt and Road Initiative (BRI): Enhancing the Collaboration in China-Central Asia Corridor" (ESCAP, 2017a), available at http://www.unescap.org/ resources/ study-ict- connectivity-belt-and- road-initiative-bri-enhancing-collaboration-china-central. Mr. Kunagorn Kunavut is a former consultant of ESCAP at the time of the preparation of the report. The report also benefited from contributions from Tiziana Bonapace, Siope Vakataki 'Ofa, Hong Joo Hahm, Guolei Cai, Eric Roeder, Jeremy Marand, Achara Jantarasaengaram, Bhavna Choudhury and Minsun Kim. The views expressed herein are those of the authors and do not necessarily reflect the views of the United Nations.
} 
of infrastructure deployment for the BRI initiative. A topology that consists of connecting Almaty (Kazakhstan) and Urumqi (China), as core nodes, is proposed based on a partial mesh topology. Over and above this core finding, the study concludes that digital infrastructure connectivity has a tendency of lagging behind the rapid opportunities evolving, and the study therefore advocates for sub-regional and regional approaches, including the BRI and Asia-Pacific Information Superhighway (AP-IS) in further expanding regional broadband networks. A key recommendation of the study is co-deployment of broadband infrastructure along passive infrastructure, as an additional cost effective means of achieving fast and affordable broadband connectivity for all.

\section{Keywords: Belt and Road Initiative; China-Central Asia Corridor infrastructure}

\section{Introduction}

Information and communications technology (ICT) is a growth sector on its own, but it also serves as the critical infrastructure to other sectors and enables various applications, such as intelligent transport systems, single windows, paperless trade and smart grid, to name a few, thus making ICT connectivity a strategic initiative which shapes the future of the region. Even though the benefits of ICT in socioeconomic development has been widely recognized, there are still disparities between and within countries when it comes to ICT infrastructure, and these deficits are expected to grow in the future (Asian Development Bank (ADB), 2016). According to an ADB report (2017), countries with higher Internet penetration reap Thailand; okuda@un.org

Kanavut K, Okuda A, Lee D, et al. (2018). "Belt and Road Initiative (BRI): Enhancing ICT connectivity in China-Central Asia corridor". Journal of Infrastructure, Policy and Development, 2(1): 116-141. doi: 10.24294 jipd.v2i1.164.

COPYRIGHT

Copyright@2018 by author (s) and EnPress Publisher LLC.

This work is licensed under the Creative Commons Attri bution-NonCommercial 4.0 International License (CC BY -NC 4.0). http://creativecommons. Org/license/by/4.0/

up to $25 \%$ more benefit from cross-border data flows than those with limited Internet penetration, and every $10 \%$ increase in broadband penetration accelerates economic growth by $1.38 \%$ in developing countries and $1.12 \%$ in developed countries. It also found that a $10 \%$ increase in broadband penetration would be correlated to $1.5 \%$ increase in labor productivity over the following five years. ${ }^{1}$ Lack of ICT infrastructure, on the other hand, seems to constrain socioeconomic development. In Asia and the Pacific, growing infrastructure deficits are compounded by demographic and urbanization pressures and financial requirements (United Nations Economic and Social Commission for Asia and the Pacific (ESCAP), $2017 \mathrm{a}){ }^{2}$ in the case of ICT infrastructure, ESCAP found various constraining factors, such as affordability, availability, resilience and reliance of broadband networks and services, as detailed below in the literature review.

An immediate problem facing infrastructure investment worldwide is the widely discussed gap between present levels of investment and future demand for infrastructure services, and the capacity of governments to meet the shortfall. The gap is estimated at US\$49 trillion in the period of 2016-2030 (McKinsey Global Institute, 2016) with most of the investment requirement in emerging economies-

\footnotetext{
${ }^{1}$ Asian Development Bank (2017). Available from: https://www.adb.org/sites/default/files/publication/227496/special-report-infrastructure. pdf.

${ }^{2}$ See also ESCAP (2017g), available from: http://www.unescap.org/sites/default/files/Asia-Pacific\%20RECI\%20Report.pdf.
} 
particularly in the power, road and telecom sectors. According to the ADB (2017), the region needs to invest over US $\$ 20$ trillion by 2030 to resolve a serious infrastructure shortage that threatens to hold back some of the world's fastest-growing economies. This requires countries across the region to double total annual spending to over US\$1.5 trillion in areas ranging from transport to basic sanitation.

In response to the significant infrastructure deficits in the region, the Belt and Road Initiative (BRI) was developed as a development strategy that coalesces the Silk Road Economic Belt and the 21st Century Maritime Silk Road. Introduced in 2013, the BRI aims to enhance connectivity and collaboration for increased economic prosperity in the region (National Development and Reform Commission (NDRC), 2015). It is an undertaking that requires careful planning, implementation and significant capital investment to build and upgrade transport, energy and ICT infrastructure. Through this ambitious project, the region's urban centers as well as remote areas will be connected, traversing challenging topography.

The BRI comprises six economic corridors that include the Bangladesh-China-India-Myanmar (BCIM) Corridor, China-Mongolia-Russia (CMR) Corridor, China-Central Asia-West Asia (CAWA) Corridor, China-Indochina Peninsular (ICP) Corridor, China-Pakistan (CP) Corridor, and New Eurasian Land Bridge (NELB) (ESCAP, 2017b). The objective of BRI is to realize and build linkages between countries along the BRI corridors through: (1) enhancing policy coordination; (2) improving infrastructure connectivity; (3) reinforcing trade and investment cooperation; (4) moving forward with financial integration; and (5) supporting people-to-people collaboration (ESCAP, 2017a).

Considering the above and as a part of the research series of ESCAP, a report (ESCAP, 2017a) was developed to: (1) examine the status of ICT connectivity in the China-Central Asia Corridor; (2) understand the challenges and opportunities of ICT connectivity; (3) propose a resilient network topology for both intra- and inter-corridor ICT connectivity in alignment with BRI; and (4) recommend the associated ICT strategies and activities.

The sub-region is characterized as highly dependent on the ease and costs of connecting to neighboring countries for Internet transit, as many countries in the sub-region are landlocked developing countries (LLDC). As a result of the geographical features and other factors, Central Asia has been experiencing insufficient international bandwidth and high transit costs to access international links. Due to desert and/or mountainous terrains, together with low populations scattered over large distances, difficulties emerge for countries in Central Asia to develop ICT infrastructure to serve people in remote and rural areas. ${ }^{3}$ These are some of the main reasons why countries in Central Asia particularly face a large digital divide. Thus, Central Asia could gain significantly from the reinforcement of ICT infrastructure connectivity in the undertaking of the BRI initiative.

Improved ICT connectivity in Central Asia through the BRI Corridor could result in improved availability and affordability of broadband networks and services in the sub-region. This study focuses on China, Kazakhstan, Kyrgyzstan, Tajikistan, Turkmenistan and Uzbekistan, with references to neighboring countries of Afghanistan, Pakistan, Turkey and Iran. Based on the findings of the above-mentioned ESCAP study and using gap analysis, this article examines the key elements and determinants in proposing a topology for the BRI China-Central Asia Corridor, an important gateway to connect countries between Asia and Europe.

\footnotetext{
${ }^{3}$ More ICT issues and challenges in Central Asia can also be found from "Improving Broadband Access in Southeast \& Central Asia" by Internet Society (ISOC).
} 


\section{Literature review}

As the importance of ICT has gained increasing recognition in the academic and development community, reasons and factors affecting the growth and patterns of ICT development, in particular the digital divide, have been studied extensively in the past.

In terms of the digital divide, now formulated as broadband divide, ESCAP (2017c) concludes that $76 \%$ of the fixed broadband subscriptions in Asia and the Pacific are found in East and Northeast Asia, and China holds more than $50 \%$ of region's ${ }^{4}$ total fixed broadband subscriptions (Central Asia holds $7 \%$ ). There are 18 ESCAP member countries with less than $2 \mathrm{f}$ ixed broadband subscriptions per 100 inhabitants in 2016 (two countries are from Central Asia), while the Republic of Korea records over 40 for the same indicator. If unaddressed, the widening broadband divide in Asia-Pacific will have negative consequences on the capabilities of countries to implement initiatives for the Sustainable Development Goals (SDGs). Judging from the standard deviation, the fixed broadband divide in the Central Asian region is estimated to widen while mobile broadband has shown improvement since 2014 . W ith the advent of Artificial Intelligence and its associated digital technology components, such as Internet of Things, Big Data and cloud computing, there is urgency to address the broadband divide for inclusive development.

Some of the reasons behind the widening digital divide are explained in terms of network design, affordability, financing and disaster risks, among other socioeconomic factors. Asia and the Pacific are typically constrained by limited access to international transit. ${ }^{5}$ According to Inderst (2016), the developing countries' backhaul networks are usually poorly meshed and follow a "river system" pattern in which networks spread from submarine landing stations and thin out into the countries' hinterlands. This "river" system poses a significant challenge in network resilience, as a point of failure in upstream cables could affect the entire downstream of end users. A limited number of fiber interconnections and international gateways across countries limit the availability of total and per-capita international bandwidth. Landlocked countries are particularly affected as they rely on a few outdated terrestrial connections and on neighboring countries to connect to regional and global cable systems.

The availability and affordability of bandwidth could be improved through efforts to interconnect national fiber-optic backbone networks with those of neighboring countries and with regional and global fiber-optic networks. According to an ESCAP study (2017d), there are many benefits to open international gateways on the broadband connectivity market in Central Asia. In some cases, the liberalization of an international gateway alone may not be sufficient to significantly reduce the price of international bandwidth. On a medium- to long-term perspective, better quality and greater affordability of broadband services may attract international companies to invest in the region.

Since 90 per cent of international traffic is routed onto submarine cables, prices for international data transit are therefore very high: for example, according to ADB (2015), double-landlocked Uzbekistan faced a hefty US $\$ 347$ per Mbps per month for international connectivity in 2012, and most other Central Asian countries faced prices of more than US $\$ 100$ per Mbps for international capacity. It shows that Azerbaijan and Kazakhstan constitute exceptions in that they enjoy relatively lower transit prices (US\$20

\footnotetext{
${ }^{4}$ Region refers to the ESCAP region. Please refer to page 102 of report by ESCAP (2017c).

${ }^{5}$ Inderst (2016). Available from: http:// www. adb.org/publications/infrastructure-investment-private-finance-and-institutional-investorsasia-global.
} 
and US\$15 per Mbps, respectively) due to the international networks they invested in their early ages.

The high international transit costs affect the affordability at user level. In Central Asia, the majority of SMEs are found actively using ICT in trade and services sectors, most prominently in Azerbaijan and Kazakhstan where Internet services are most affordable (ESCAP, 2017e). E-commerce is set to grow in Central Asia, once hurdles are overcome, highlighting the need for affordable, high-speed and resilient Internet and broadband access.

In the area of financing, ESCAP (2017f) reviewed the effectiveness of Universal Access and Service Funds (UASFs) in expanding broadband networks and Internet usage in Asia and the Pacific. In order to boost connectivity and finance ICT infrastructure projects in under-served areas, Universal Access and Service Funds were developed in certain Asia-Pacific countries. Although this financing mechanism aims to encourage telecom operators to go into areas where there is neither the density nor the capital, the empirical evidence did not show a corresponding increase in broadband adoption among the surveyed countries. From the findings, countries without UASFs seemed to have outperformed those with UASFs in terms of broadband adoption.

In Central Asia, building resilient ICT is vital to mitigate disaster risks and promote resilient development since ICT is highly exposed and vulnerable to many disasters (ESCAP, 2017e). As one of the most seismically active areas in the world with a majority of the population concentrated within areas of high to very high seismic hazards, more emphasis could be placed on ne twork redundancy and diversification in the development of the ICT infrastructure.

The above literature review illustrates the challenges the countries along the Corridor face in the form of digital divide, financing, disaster risks and the need for e-resilience, limited international transit and connectivity, and affordability, among others.

\section{Approach and methodology}

The main approach used in this study to propose the topology for the China-Central Asia Corridor is the "gap analysis". Gap analysis typically involves the comparative analysis between current state (As-Is) and future state (To-Be). For this study, gaps will be identified, which could consequently lead to effective ICT strategic planning and network topology design. The methodology used to accomplish this work is divided into four major stages, i.e., (1) BRI Characterization; (2) Future State Analysis; (3) Current State and Gap Analysis; and (4) Solution Architecture, as depicted in Figure 1. 


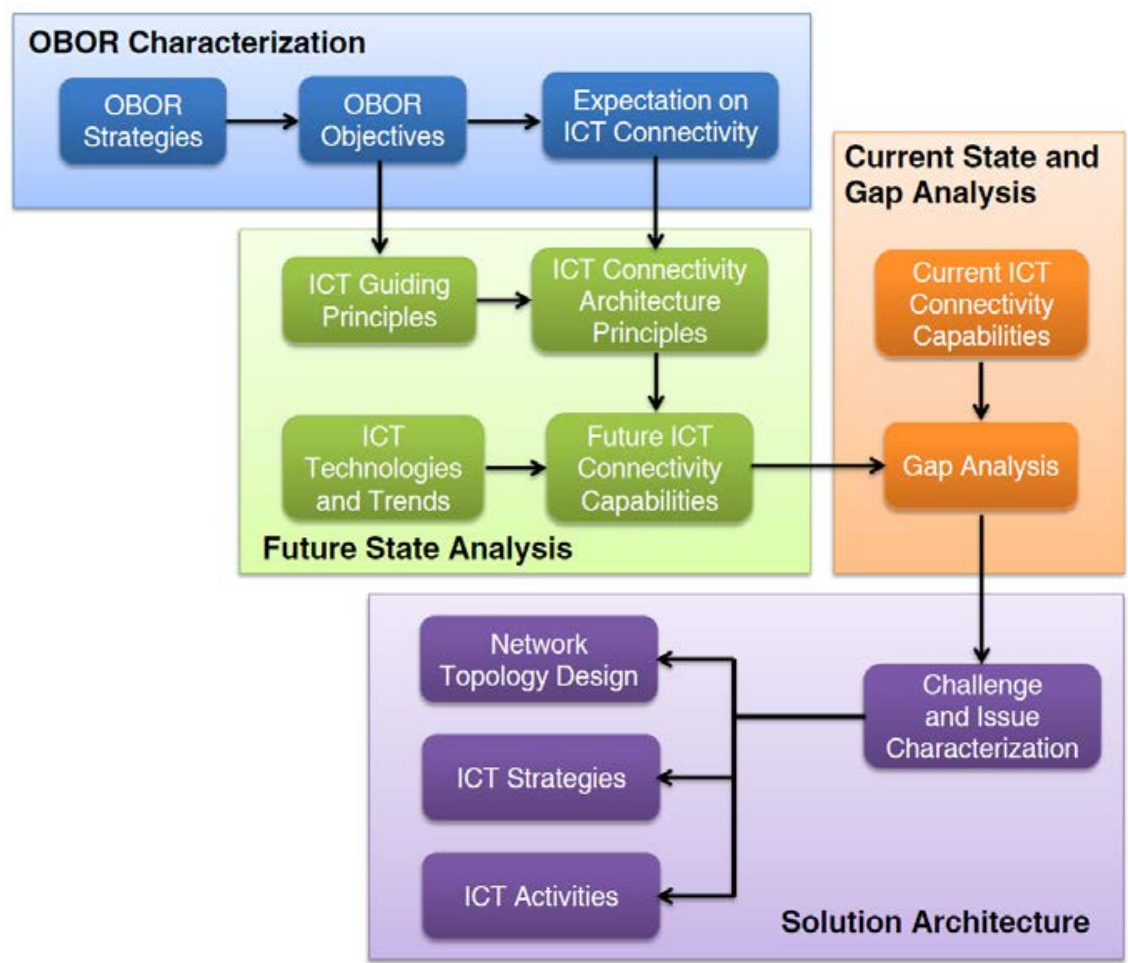

Figure 1. Approach and methodology

Source: Developed by Kunagorn Kunavut, based on the gap analysis methodology

The first stage is intended to study and characterize the BRI to understand both requirements and expectations on ICT connectivity. After all, the basic information regarding the BRI initiative must be collected and studied in detail to clearly understand its strategies, objectives and expectations on ICT to effectively support the BRI initiative. This stage is an essential stage to determine the future state of ICT connectivity in the China-Central Asia Corridor.

Once the BRI requirements and expectations on ICT connectivity are obtained, current and emerging ICT trends and technologies (including recommendations and best practices) are studied to identify future ICT infrastructure and operation capabilities. These include: (1) ICT infrastructure technologies to be proposed for inter- and intra-corridors ICT connectivity; and (2) electronic application trends (e.g., egovernment, e-commerce and so on) to be supported on top of ICT infrastructure. ${ }^{6}$

The third stage is the data collection and assessment to obtain the current state of ICT connectivity. Some examples of data and information to be collected include broadband penetration, Internet penetration, Internet prices, international links and cross-border fiber-optic cable, among others. Once future and current states of ICT connectivity are determined, gap analysis could be applied to identify the gaps between the requirements/expectations on ICT connectivity and the results obtained from the current state analysis. The framework for the principal areas to be considered in studying of ICT connectivity for BRI is carefully developed, as shown in Figure 2. Based on the data and information obtained from the previous stages, gaps are expected to emerge within the framework.

\footnotetext{
${ }^{6}$ Due to the page limitation, this article focuses on the first point of ICT infrastructure.
} 


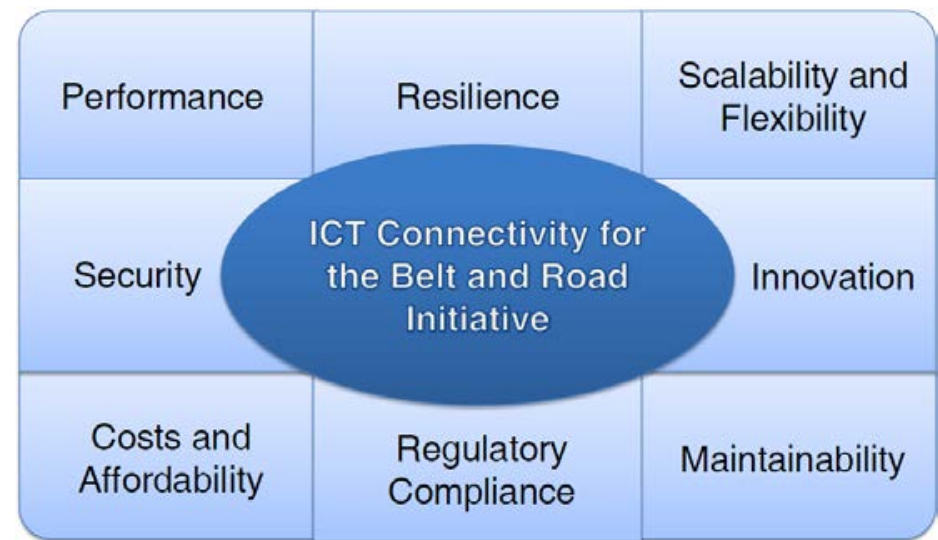

Figure 2. Principal areas in studying of ICT connectivity for BRI

Source: Designed by Kunagorn Kunavut

After gap analysis is successfully carried out, the results obtained from this stage could be used as baseline at the last stage (solution architecture) to formulate effective solutions for high-level architecture and technologies that meet and fulfill those requirements and bridge gaps between the current state and future state. This typically includes ICT strategies and activities which must be considered to successfully strengthen ICT connectivity.

The characterization of BRI and future state of ICT requirements and expectations are detailed in the ESCAP report (ESCAP, 2017a) after extensive document review. In this chapter, the data collected and analyzed to determine the current state and trends are presented to justify the proposed topology and policy recommendations at the end of the article.

\section{Current state and trends in the China-Central Asia Corridor}

\subsection{Demographic and economic indicators}

In 2000-2013, the average share of intangible investment in $\mathrm{GDP}^{7}$ is relatively higher in the US (4.2\%) than in the EU14 (3.1\%) as well as in the four new EU Member States (NMS) included in the analysis $(2.2 \%)$ (Figure 2). Moreover, national accounts data suggest that the GDP share of tangible investment in the three areas $(7.7 \%, 9.2 \%$ and $16.0 \%$, respectively) is relatively higher than the intangible share.

The China-Central Asia Corridor is an integral part which forms the China-Central Asia-West Asia Corridor and provides connectivity to other countries in Asia and the Pacific. Hence, it is essential to be aware of the general socioeconomic and ICT development status of countries in the China-Central Asia Corridor. The countries which are reviewed in this chapter are (1) China, (2) Kazakhstan, (3) Kyrgyzstan, (4) Tajikistan, (5) Turkmenistan and (6) Uzbekistan.

In addition to the demographic indicators in Table 1, the GDP of China is US\$11,199,145 million, thereby ranked second, while the GDP of Kazakhstan is US\$137,278 million, thereby ranked $55^{\text {th }}$,

\footnotetext{
${ }^{7}$ In this section GDP refers to officially measured gross domestic product available from national accounts.
} 
according to the GDP world ranking in 2015 by World Bank. ${ }^{8}$ All the Central Asian countries listed fall below the world average in terms of GDP per capita of US\$10,191.31. Moreover, China, Kazakhstan and Turkmenistan are categorized as u pper-middle income countries, ${ }^{9}$ while Kyrgyzstan, Tajikistan and Uzbekistan are categorized as lower-middle income countries. The main indicator used to characterize the income levels is GNI per capita, of which the world average is US\$10,299.

Table 1. Demographic indicators in the China-Central Asia Corridor

\begin{tabular}{|c|c|c|c|}
\hline Economy & Population (thousand) & $\begin{array}{c}\text { Population Density } \\
\text { (people per square km of land area) }\end{array}$ & $\begin{array}{c}\text { Urban Population } \\
\text { (per cent of total population) }\end{array}$ \\
\hline China & $1,378,665$ & 147 & 57 \\
\hline Kazakhstan & 17,797 & 7 & 53 \\
\hline Kyrgyzstan & 6,083 & 32 & 36 \\
\hline Tajikistan & 8,735 & 63 & 27 \\
\hline Turkmenistan & 5,663 & 12 & 50 \\
\hline Uzbekistan & 31,848 & 75 & 36 \\
\hline
\end{tabular}

Source: "World Development Indicators" by World Bank (2017)

China is also the key trading partner in Central Asia: more than 40 per cent of total trade in Kyrgyzstan, Tajikistan and Turkmenistan is with China. ${ }^{10}$ In addition, China is ranked number one in exports in Turkmenistan, and China is also the first ranked country in imports to Kyrgyzstan and Uzbekistan. This trade relationship between China and Central Asia clearly illustrates the strong connectivity and collaboration between these nations. In addition, regarding energy, China has imported oil and gas from Central Asia for decades.

\subsection{ICT policies and strategies}

In the ICT sector, government policy is another key factor to promote the development of ICT infrastructure. In this section, the government policies of countries in the China-Central Asia Corridor are briefly discussed. The "Broadband China" strategy was introduced in 2013 to speed up broadband development and build the next-generation information infrastructure (Ministry of Industry and Information Technology (MIIT) of the People's Republic of China, 2016).

Kazakhstan proposed the state program "Informational Kazakhstan-2020" which was approved in 2013 to move forward to information society (Electronic Government of the Republic of Kazakhstan, 2017). This program aimed at advancing affordable innovation and information technology infrastructure. Furthermore, the National Sustainable Development Strategy of Kyrgyz Republic 2013-2017 was also developed in the same year (National Council for Sustainable Development of the Kyrgyz Republic, 2015). In this strategy, the main priority is to transform Kyrgyzstan from a transport-deadlock country into a transit one. In addition, there are many projects related to the optical fiber trunk lines and the

\footnotetext{
${ }^{8}$ World Development Indicators 2016, “GDP ranking”, World Bank. The data can be found at: https://data.worldbank.org/indicator/NY.GDP. PCAP.CD.

${ }^{9}$ The income levels by country used in this study are categorized by World Bank, and there are four groupings: low, lower-middle, uppermiddle and high. The details can be found at http://data.worldbank.org/country.

${ }^{10}$ Direction of Trade Statistics (DOTS), International Monetary Fund. Available from https://data.world/imf/direction-of-trade-statistics-dots.
} 
migration from analog TV and radio broadcasting to digital one.

Tajikistan's strategy, "ICT for the Development of the Republic of Tajikistan", was approved in 2003 to guarantee effective introduction and development of ICT in the country (Government of the Republic of Tajikistan, 2009). This strategy focused on ICT infrastructure development as well as the implementation of new ICT applications and information security. There seems to be no concrete ICT policy in Turkmenistan. However, many ICT projects were carried out in various sectors including banking and finance, education and so on. In Uzbekistan, a set of ICT development projects have been implemented since 1995, which aimed at construction and improvement of national ICT infrastructure such as backbone infrastructure in regional centers. More information can also be found from Measuring the Information Society Report (International Telecommunications Union (ITU), 2017a).

\subsection{ICT usage and forecasted bandwidth requirements}

The number of individuals using the Internet in China and Kazakhstan is over the world average at 53.2 per cent and 76.8 per cent, respectively, as illustrated in Figure 3, while it is nearly the same as the world average in Uzbekistan at 46.8 per cent. However, less than 35 per cent of individuals use the Internet in Kyrgyzstan, Tajikistan and Turkmenistan. According to fixed infrastructure subscriptions (including both fixed telephone and fixed broadband subscriptions), only China and Kazakhstan exhibit the number of fixed telephone networks subscriptions above the world average at 14.7 per cent and 23.2 per cent, respectively. Furthermore, Kyrgyzstan, Tajikistan, Turkmenistan and Uzbekistan have low fixed broadband penetration (less than 12.2 per cent). This fact coincides with the statistic in telecommunications infrastructure sub-index shown in Figure 3 which may depict insufficient fixed ICT infrastructure in these countries.

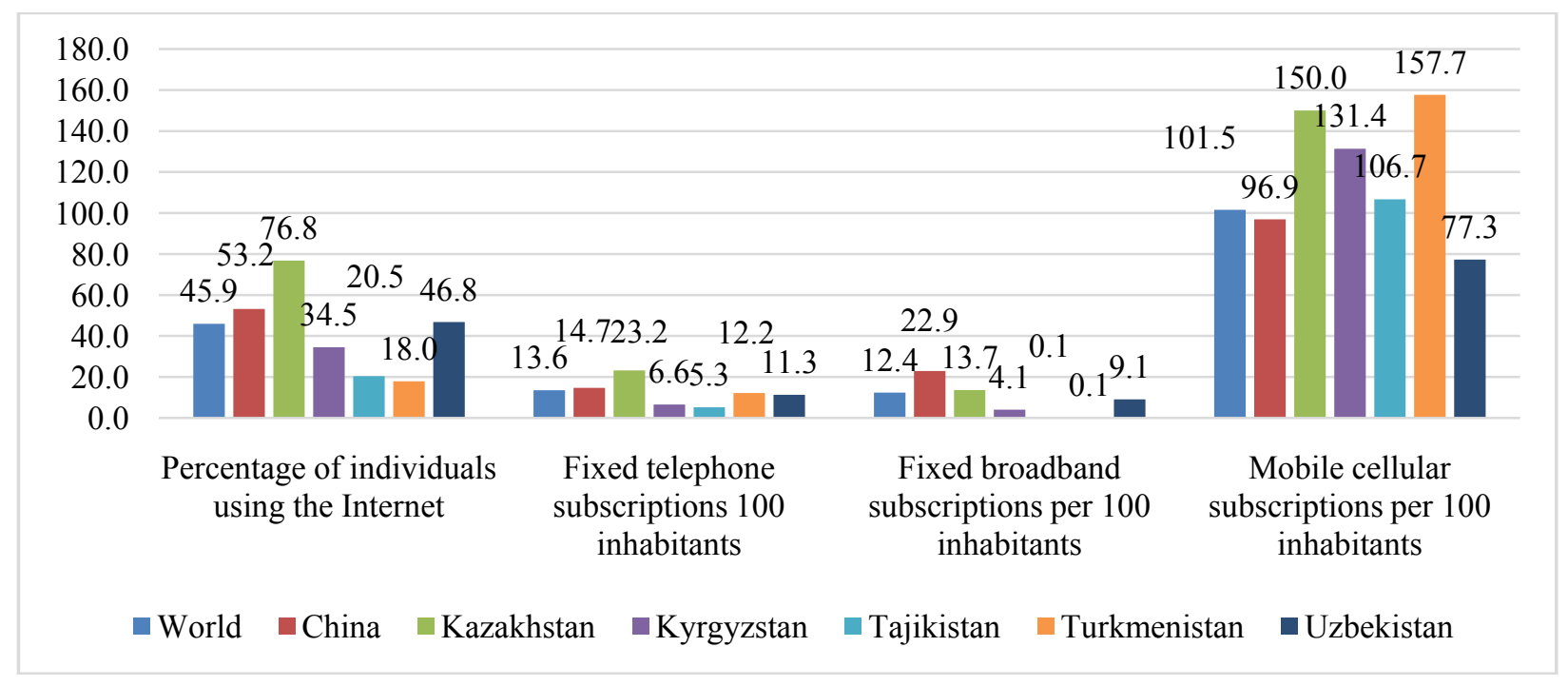

Figure 3. ICT penetration (per 100 inhabitants) in China and Central Asia

Source: "ITU World Telecommunication/ICT Indicators database”, ITU (2017b)

However, the penetration of mobile cellular telephone subscriptions per 100 inhabitants is quite high in China and Central Asia and especially in Kazakhstan and Turkmenistan with values of over 100, which 
illustrates that a person may have more than one mobile cellular telephone subscription. The mobile cellular telephone subscriptions of Kyrgyzstan is at 131.4, higher than the world average, while China exhibits a value slightly lower than average at 96.9 The lowest value is exhibited by Uzbekistan at 77.3 mobile cellular telephone subscriptions per 100 inhabitants.

Mobile broadband networks ( $3 \mathrm{G}$ or above) now reach 84 per cent of the global population but only 67 per cent of the rural population. To enhance the quality of using the Internet, Long-Term Evolution (LTE) networks are gaining presence, and 53 pe $\mathrm{r}$ cent of the global population or around 4 bi llion people subscribe to these LTE networks. ${ }^{11}$

According to the historical data and estimates by Terabit Consulting (ESCAP, 2017e), international bandwidth $^{12}$ demand is expected to grow exponentially, which underlines the urgent need for building broadband connectivity. A forecasted increase in international bandwidth is expected in the China-Central Asia-West Asia Corridor. International bandwidth in Gbps is expected to grow by 364.5 pe $\mathrm{r}$ cent from 2016 to 2020 (see Figure 4). Corporate data is forecasted to account for approximately 17.5 per cent of total international bandwidth for the period 2016-2020, while the rest will be Internet bandwidth.

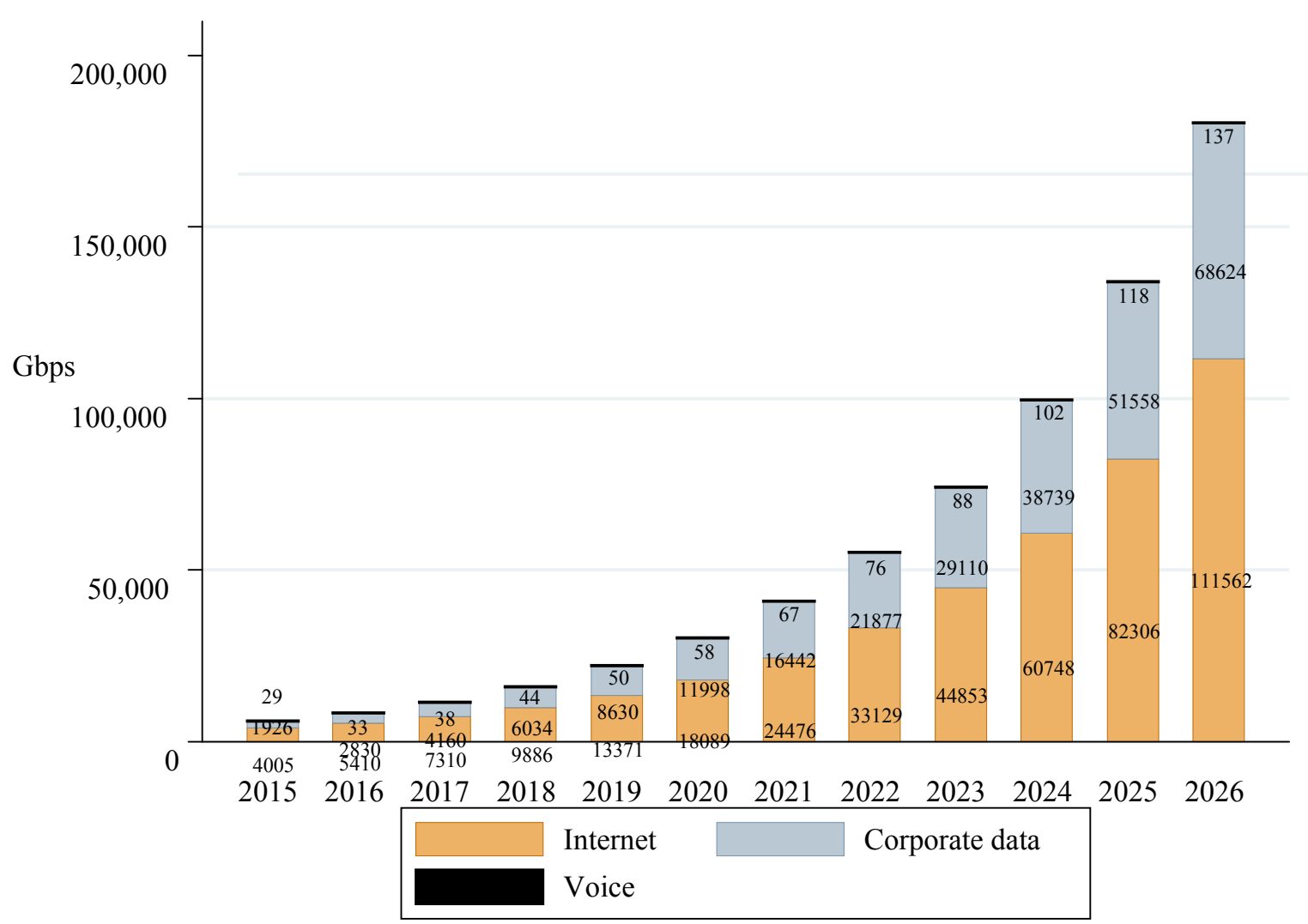

Figure 4. Forecasted international bandwidth along the China-Central Asia-West Asia Corridor (Gbps), 2015-2026

${ }^{11}$ The details about mobile network coverage and technologies can be found from "ICT Facts and Figures 2017" by ITU (2017b).

12 Terabit Consulting defines international Internet bandwidth as activated downstream capacity carrying Internet traffic. For example, if an operator or ISP activates a 10 Gbps link between Bangkok and Amsterdam for public IP transport, then it would be counted as a full 10 Gbps, even if the total traffic on it is only 6 Gbps during peak hour. 


\subsection{Affordability}

Table 2 shows that Central Asian countries are estimated to have lower affordability in various telecommunications services than in countries of other corridors, although the comparative figures are not available for Tajikistan, Uzbekistan and Turkmenistan.

Table 2. China-Central Asia-West-Asia Corridor

\begin{tabular}{|c|c|c|c|c|c|c|}
\hline Country & IPB 2014 & $\begin{array}{c}\text { Fixed telephone } \\
\text { sub-basket as per } \\
\text { cent of GNI per } \\
\text { capita, } 2014\end{array}$ & $\begin{array}{l}\text { Mobile-cellular sub- } \\
\text { basket as per cent of } \\
\text { GNI per capita, } 2014\end{array}$ & $\begin{array}{l}\text { Fixed broadband sub- } \\
\text { basket as per cent of } \\
\text { GNI per capita, } 2014\end{array}$ & $\begin{array}{l}\text { GNI per } \\
\text { capita, } \\
\text { USD, } \\
2014 *\end{array}$ & Rank \\
\hline China & 1.7 & 0.9 & 0.7 & 3.6 & 6553 & 67 \\
\hline Kazakhstan & 0.8 & 0.3 & 0.9 & 1.1 & 11538 & 23 \\
\hline Kyrgyzstan & 5.6 & 1.2 & 4.9 & 10.7 & 1209 & 117 \\
\hline Tajikistan & \multicolumn{6}{|c|}{ Not included in the dataset } \\
\hline Uzbekistan & \multicolumn{6}{|c|}{ Not included in the dataset } \\
\hline Turkmenistan & \multicolumn{6}{|c|}{ Not included in the dataset } \\
\hline Iran & 0.5 & 0.1 & 0.4 & 0.9 & 5774 & 7 \\
\hline Turkey & 1.6 & 1.2 & 2.5 & 1.1 & 10959 & 63 \\
\hline Greece & \multicolumn{6}{|c|}{ Non-ESCAP member } \\
\hline EU & \multicolumn{6}{|c|}{ Non-ESCAP member } \\
\hline
\end{tabular}

Source: ESCAP analysis based on the figures from "Measuring the Information Society Report 2015" published by ITU (2017a) and the data for GNI in the World Development Indicators (World Bank, 2015). Note: * - latest year available.

\subsection{Existing and planned fiber-optic network projects}

To increase availability and affordability of telecommunication services, various fiber-optic cable networks have been planned and implemented along this corridor as highlighted in Table 3.

Table 3. Number of children and percentage of female spouses who participated in productive work prior to the survey

\begin{tabular}{|c|c|c|c|c|}
\hline Project & Description & Type & ESCAP Countries & Completion \\
\hline $\begin{array}{l}\text { Turkmenistan } \\
\text { deployed new } \\
\text { national } \\
\text { backbone } \\
\text { network }\end{array}$ & $\begin{array}{l}\text { The Ministry of Communications of Turkmenistan has } \\
\text { deployed a new national backbone network that } \\
\text { connects all major cities of Turkmenistan with cross- } \\
\text { border transit and subsea transmission links. The } \\
\text { network has a total system capacity of up to } 9.6 \text { Tbps } \\
\text { per fiber pair. }{ }^{13}\end{array}$ & Terrestrial & Turkmenistan & July 2016 \\
\hline $\begin{array}{c}\text { Silk Road } \\
\text { Gateway } 1 \\
\text { (SRG1) cable } \\
\text { system linking } \\
\text { Pakistan and } \\
\text { Oman to be ready } \\
\text { in } 2017\end{array}$ & $\begin{array}{l}\text { Telecommunications companies Omantel and Multinet } \\
\text { Pakistan announced that they are working on a } 20- \\
\text { Tbps submarine cable network linking Pakistan and } \\
\text { Oman. }{ }^{14} \text { The network will connect Karachi with } \\
\text { Muscat (with a planned future extension to Gwadar in } \\
\text { Pakistan). After completion, Pakistan would get } \\
\text { around } 200 \text { Gbps of extra bandwidth. The } 1030-\mathrm{km} 20-\end{array}$ & Submarine & $\begin{array}{l}\text { Pakistan, } \\
\text { Afghanistan, } \\
\text { China, Iran, } \\
\text { Turkmenistan, } \\
\text { Tajikistan }\end{array}$ & Q4 2017 \\
\hline
\end{tabular}

\footnotetext{
${ }^{13}$ TeleGeography (2016). Available from: https://www.telegeography.com/products/commsupdate/articles/2016/07/15/cable-compendium-aguide-to-the-weeks-submarine-and-terrestrial-developments/

${ }^{14}$ Bolger N (2016). Available from: http://www.capacitymedia.com/Article/3552917/Omantel-and-Multinet-Pakistan-announce-Silk-RouteGateway.html.
} 
Table 3. Continued

\begin{tabular}{|c|c|c|c|c|}
\hline Project & Description & Type & ESCAP Countries & Completion \\
\hline & $\begin{array}{l}\text { Tbps SRG1 is said to have onwards connectivity to } \\
\text { Afghanistan, China, Iran, Turkmenistan and Tajikistan. }\end{array}$ & & & \\
\hline $\begin{array}{l}\text { Construction of } \\
\text { terrestrial link } \\
\text { between Kyrgyz } \\
\text { Republic and } \\
\text { China completed }\end{array}$ & $\begin{array}{l}\text { The chairman of Kyrgyzstan's State Committee for } \\
\text { ITC has revealed that construction work on a n } \\
\text { alternative fiber-optic route linking Kyrgyzstan and } \\
\text { China has been completed. The Naryn-Torugart } \\
\text { network is the second alternative route build by RTC } \\
\text { and China Telecom, in addition to the in-operation } \\
\text { Bishkek-Osh route. The two companies are understood } \\
\text { to now be planning to deploy a third diverse fiber-optic } \\
\text { route, linking Balykchy and Naryn. }{ }^{16}\end{array}$ & Terrestrial & $\begin{array}{l}\text { China, Kyrgyz } \\
\text { Republic }\end{array}$ & Not disclosed \\
\hline
\end{tabular}

Table 4. International fiber routes in China and Central Asia

\begin{tabular}{|c|c|c|c|c|}
\hline Economy & $\begin{array}{c}\text { International } \\
\text { Bandwidth } \\
\text { (Gbps) }\end{array}$ & Landline Routes + Submarine Routes & $\begin{array}{c}\text { Number of Main } \\
\text { Routes (Landline } \\
\text { + Submarine) }\end{array}$ & $\begin{array}{c}\text { International } \\
\text { Bandwidth Per } \\
\text { Capita (Kbps) }\end{array}$ \\
\hline China & 5,392 & $\begin{array}{l}\text { Landline: DREAM; Trans Asia-Europe (TAE); Trans- } \\
\text { Eurasian Information Super Highway (TASIM); Greater } \\
\text { Mekong Sub-region (GMS); China-Kazakhstan (two routes } \\
\text { via Alashankou and Kongos); China-Kazakhstan; China- } \\
\text { Tajikistan; China-Kyrgyzstan; China-Mongolia; China- } \\
\text { Russia (three routes via Manzhouli, Heihe and Suifenhe); } \\
\text { China-Vietnam; China-Lao PDR; China-Myanmar; China- } \\
\text { India. } \\
\text { Submarine: EAC-C2C; Trans-Pacific Express (TPE); } \\
\text { APCN-2; Asia-Pacific Gateway (APG); China-U.S. Cable } \\
\text { Network (CHUS); New Cross Pacific (NCP); FLAG Europe- } \\
\text { Asia (FEA); SeaMeWe-3; Taiwan Strait Express-1 (TSE-1); } \\
\text { Southeast Asia Japan Cable (SJC). }\end{array}$ & $17+10$ & 3.93 \\
\hline Kazakhstan & 1,082 & $\begin{array}{l}\text { DREAM; TAE; TASIM; China-Kazakhstan, Kazakhstan- } \\
\text { Kyrgyzstan (two routes via Merke and Korday); Northern } \\
\text { Kazakhstan-Russia; North-western Kazakhstan-Russia; Western } \\
\text { Kazakhstan-Russia; Kazakhstan-Turkmenistan; Kazakhstan- } \\
\text { Eastern Uzbekistan; Kazakhstan-Western Uzbekistan }\end{array}$ & $12+0$ & 61.67 \\
\hline Kyrgyzstan & 30.1 & $\begin{array}{l}\text { TAE; Kyrgyzstan-Tajikistan; China-Kyrgyzstan; Kazakhstan- } \\
\text { Kyrgyzstan ( } 2 \text { routes via Merke and Korday); Kyrgyzstan - } \\
\text { Uzbekistan }\end{array}$ & $6+0$ & 5.05 \\
\hline Tajikistan & 4.5 & $\begin{array}{l}\text { Afghanistan-Tajikistan; China-Tajikistan; Kyrgyzstan-Tajikistan; } \\
\text { Tajikistan-Uzbekistan }\end{array}$ & $4+0$ & 0.53 \\
\hline Turkmenistan & 2.4 & $\begin{array}{l}\text { TAE; Kazakhstan-Turkmenistan; Afghanistan-Turkmenistan } \\
\text { (eastern and western links) }\end{array}$ & $4+0$ & 0.45 \\
\hline Uzbekistan & 30.7 & $\begin{array}{l}\text { TAE; Kazakhstan-Eastern Uzbekistan; Kazakhstan-Western } \\
\text { Uzbekistan; Kyrgyzstan-Uzbekistan; Tajikistan-Uzbekistan; } \\
\text { Afghanistan-Uzbekistan }\end{array}$ & $6+0$ & 0.98 \\
\hline
\end{tabular}

Source: Various sources ${ }^{17}$

\footnotetext{
${ }^{15}$ Times of Oman (2016). Available from: http://timesofoman.com/article/95534/Business/Omantel-connects-Africa-to-Asia-with-subseacable-systems.

${ }^{16}$ TeleGeography (2017). Available from: https://www.telegeography.com/products/commsupdate/articles/2017/01/13/cable-compendium-aguide-to-the-weeks-submarine-and-terrestrial-developments/.

${ }^{17}$ Information is based on "An In-Depth Study of Broadband Infrastructure in North and Central Asia" by ESCAP (2014); "Updated Analysis of the Broadband Infrastructure in the ESCAP Region" by ESCAP (2016b); "Statistical Report on Internet Development in China" by CNNIC (2016); "ITU Interactive Transmission Map"; and "TeleGeography Submarine Cables Map".
} 
The details of international links are listed in Table 4. Note that, in this table, baseline information is updated using the information from the China Internet Network Information Center (CNNIC).

By focusing on the international bandwidth per capita in Table 4, it becomes evident that Kazakhstan has the largest bandwidth per capita at $61.67 \mathrm{Kbps}$, followed by Kyrgyzstan at $5.05 \mathrm{Kbps}$, whereas bandwidth per capita of China is $3.93 \mathrm{Kbps}$. Although China has very large international bandwidth, it is ranked third among these countries in terms of bandwidth per capita because of its large population size, while the bandwidth per capita of other countries is usually less than $1 \mathrm{Kbps}$. In addition, it is important to note that ITU and World Bank also use different metrics to measure international Internet capacity in terms of international Internet bandwidth per Internet user because each country has a different level of Internet penetration. From Figure 5, Kazakhstan is the only country in this region that has international bandwidth per user near the world average at $51.49 \mathrm{Kbps}$, while other countries are far below the average (1.29 to $8.17 \mathrm{Kbps})$. Note that information in this figure was obtained in 2014 and is expected to have improved by now.

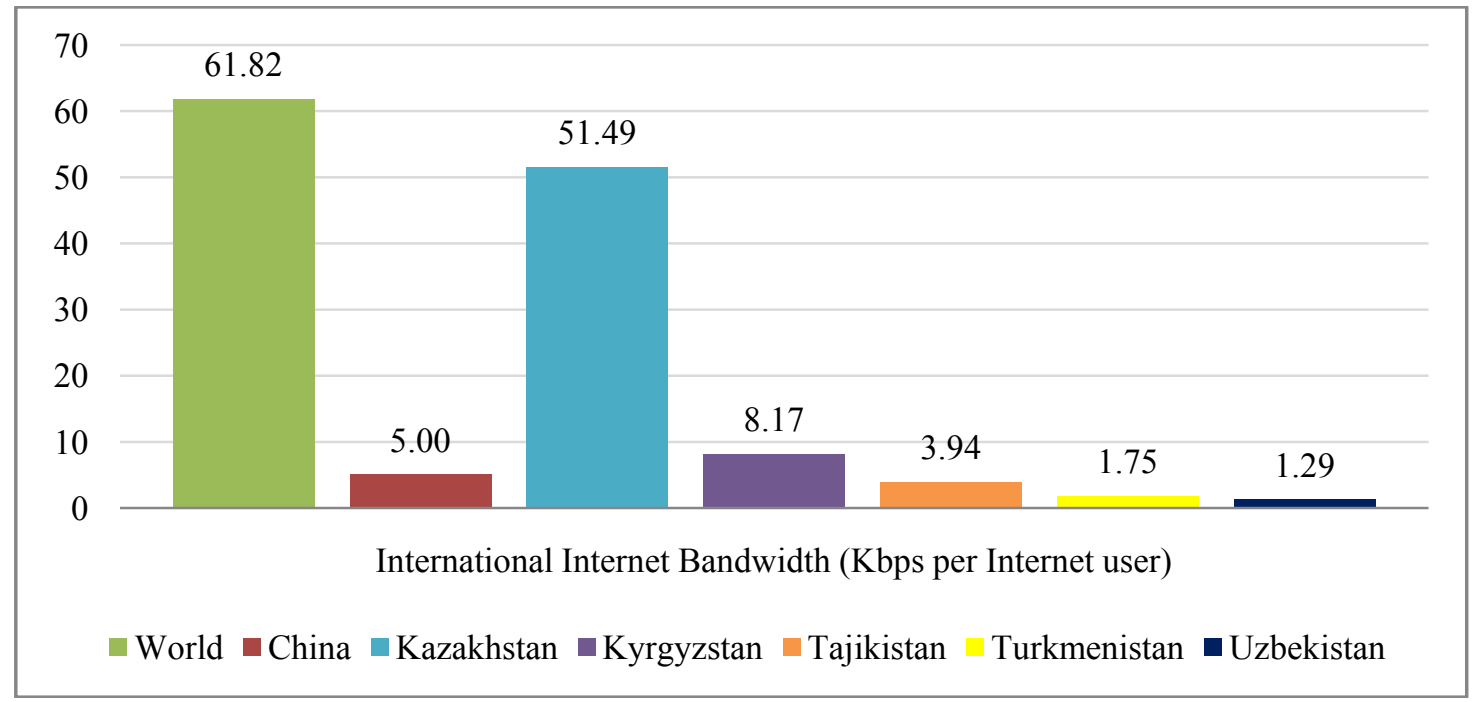

Figure 5. International internet bandwidth per internet user in China and Central Asia

Source: “World Development Indicators: The Information society" by World Bank (2014) (latest data is as of 2017).

China has six major backbone networks. Among these networks, China Telecom has the largest international bandwidth of 3,223.63 Gbps, followed by China Unicom and China Mobile with bandwidth of 1,414.87 Gbps and 645.07 Gbps, respectively. Notably, the total international bandwidth of China is 5,392.12 Gbps, which is larger than the total international bandwidth of Central Asia. The country that has the largest international bandwidth in Central Asia is Kazakhstan with 1,082 Gbps, while Turkmenistan has the lowest international bandwidth at 2.4 Gbps (ESCAP, 2016a; CNNIC, 2016).

Figure 6 depicts ICT infrastructure in terms of both terrestrial and submarine cables in China and Central Asia. It illustrates that China has submarine routes to digitally interconnect with other countries, whereas countries in Central Asia are largely classified as LLDC due to lack of territorial access to the sea. Hence, international connectivity is highly dependent on their neighboring countries, and these international links are typically costly and limited by low-capacity cross-border fiber-optic links. Thus, 
most countries in Central Asia usually experience inadequate international bandwidth and high transit cost to access international links.

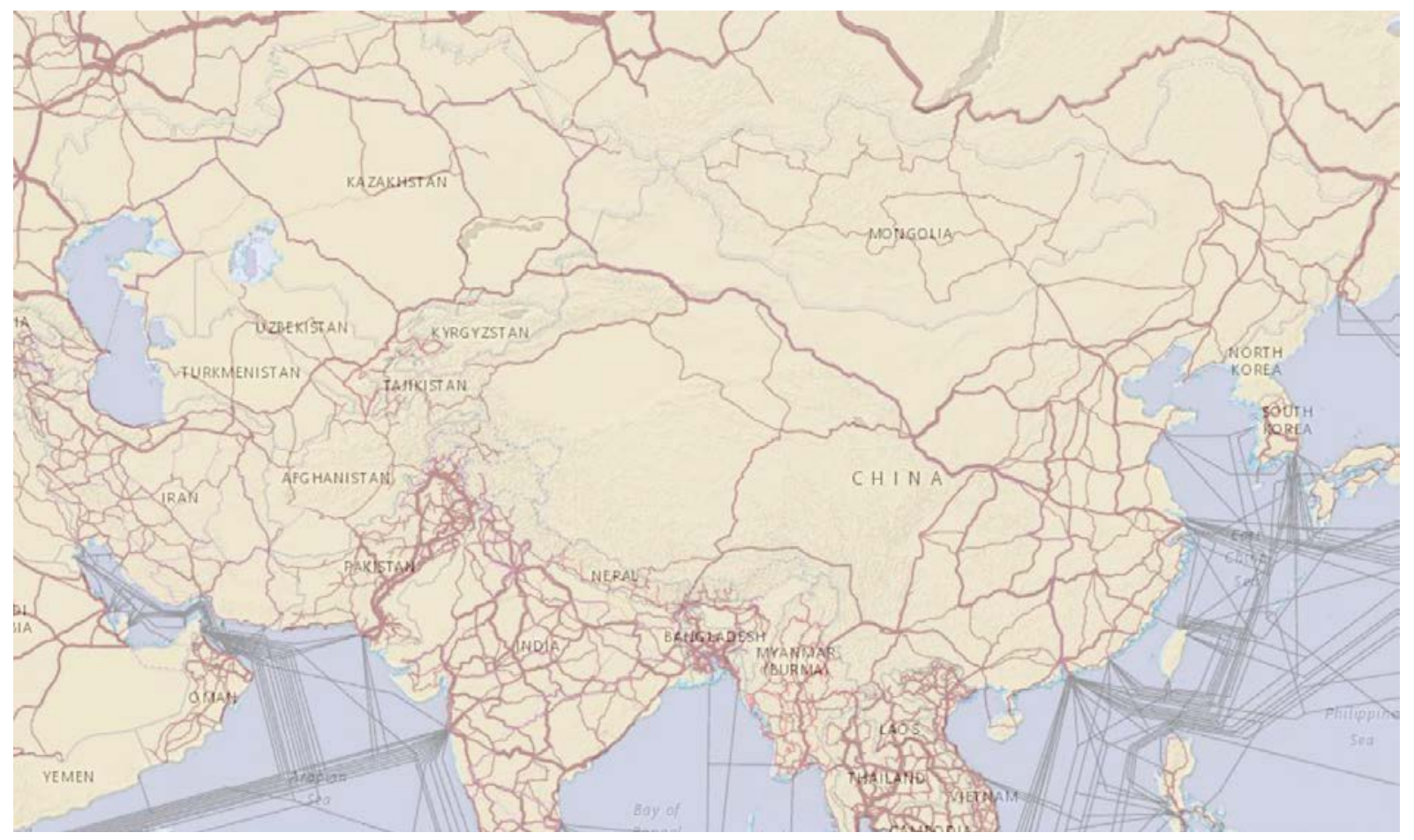

Figure 6. Landline and submarine cables in China and Central Asia

Source: Adapted from "AP-IS Interactive Transmission Map" and "National Geographic Mapmaker Interactive". 18

An international gateway enables connection between countries. International gateway is defined in the ESCAP report (2017d) as "any facility through which electronic communications (voice, data and video) can be sent between the domestic networks of one country and another." China has cross-border fiber-optic cables to three adjacent countries in Central Asia, which are Kazakhstan, Kyrgyzstan and Tajikistan. Central Asia (via China-Kazakhstan, China-Kyrgyzstan and China-Tajikistan routes) can only connect to China via the regional international gateway in Urumqi. Moreover, the Russian Federation (via Harbin gateway) and Mongolia can connect to China via the Beijing international gateway, while China can also connect to Myanmar and Lao PDR via the regional international gateway in Kunming, and to Vietnam via the Nanning gateway (ESCAP, 2017a). The logical diagram of physical topology of China and Central Asia is depicted in Figure 7.

In terms of link capacity between China and Central Asia, China and Kazakhstan are connected using China-Kazakhstan cross-border fiber-optic routes, and with the TAE line with a capacity of $622 \mathrm{Mbps}$ using Synchronous Digital Hierarchy (SDH) technology. ${ }^{19}$ Additionally, there is a China-Kyrgyzstan

\footnotetext{
${ }^{18}$ Available at http://www.unescap.org/our-work/ict-disaster-risk-reduction/asia-pacific-information-superhighway/asia-pacific-informationsuperhighway-maps.

${ }^{19}$ More information about cross-border fiber links between China and Central Asia can be found from "An In-Depth Study of Broadband Infrastructure in North and Central Asia” by ESCAP (2017a).
} 
cross-border link with a capacity of $2.5 \mathrm{Gbps}$ with WAN technology. Based on obtained information, the WAN technology used to interconnect multiple countries in this region utilizes SDH and the maximum capacity is $30 \mathrm{Gbps}$ (there are only two international fiber links between Kazakhstan and Kyrgyzstan), while the minimum is only $155.52 \mathrm{Mbps}$. The main WAN technology used in China's national broadband networks is called Dense Wavelength Division Multiplexing (DWDM) (ESCAP, 2017a).

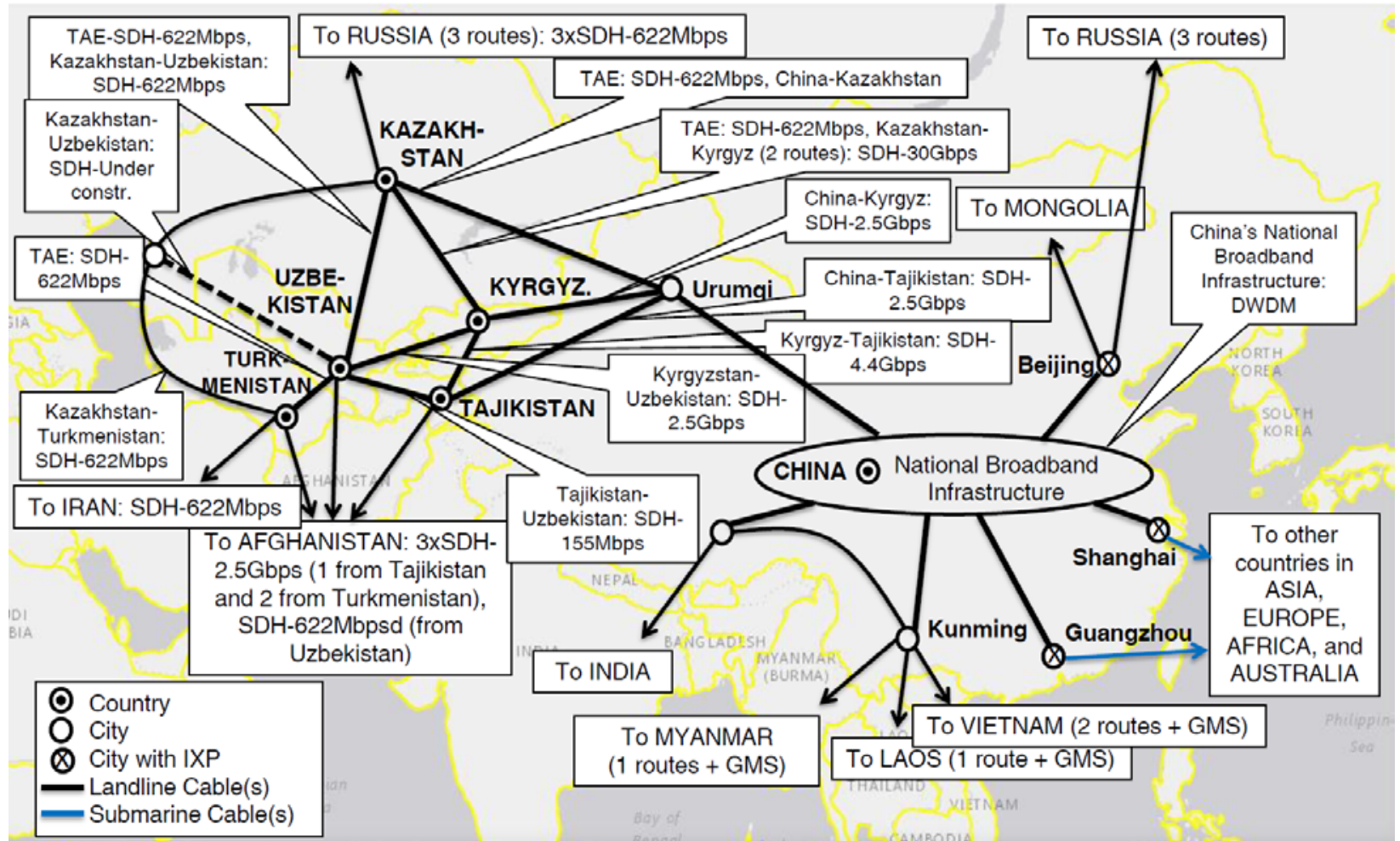

Figure 7. Logical diagram of physical topology in China and Central Asia

Source: Various sources ${ }^{20}$

\subsection{Internet Exchange Points (IXPs)}

Another important factor to determine the current state is the Internet Exchange Point (IXPs). The Internet Society has defined Internet Exchange Points (IXPs or IXs) as "p hysical locations where different networks connect to exchange Internet traffic via common switching infrastructure" (ISOC, 2015). This switching infrastructure typically includes switches, routers, cablings and interfaces. IXPs are usually implemented across various locations in different countries to allow local Internet traffic to be locally exchanged. Then, local traffic between two networks in the same country can be directly exchanged within IXPs without indirectly passing through the international link. This consequently reduces the transit cost over international links. Because network operators' OPEX (operational expenditure in terms of cost associated in traffic exchange) is reduced, Internet access cost for Internet users is also expected to be decreased (ESCAP, 2017a).

\footnotetext{
${ }^{20}$ Information is based on "An In-Depth Study of Broadband Infrastructure in North and Central Asia" by ESCAP (2014; 2017a) and "AP-IS Interactive Transmission Map ”
} 
In China, there are three carrier-neutral IXPs (called CHN-IX) in Beijing, Shanghai and Guangzhou ${ }^{21}$ as depicted in Figure 8. All six major service providers for backbone networks also connect to these three locations of CHN-IX. In addition, there are three IXPs in Central Asia: one is in Tashkent, Uzbekistan, which is TAS-IX; ${ }^{22}$ one is in Almaty, Kazakhstan, called KAZ-IX; and another is in Bishkek, Kyrgyzstan (Kyrgyz-IX). ${ }^{23}$ However, the Network Startup Resource Center (NSRC) reported that KAZ-IX currently has no pe ering member ${ }^{24}$ (not currently functional). In addition, according to a report from the Internet Society, ${ }^{25}$ Kyrgyz-IX currently does not allow international ISPs, content providers or data-center operators to exchange traffic at the IXP. Note that both KAZ-IX and Kyrgyz-IX are not included in this figure.

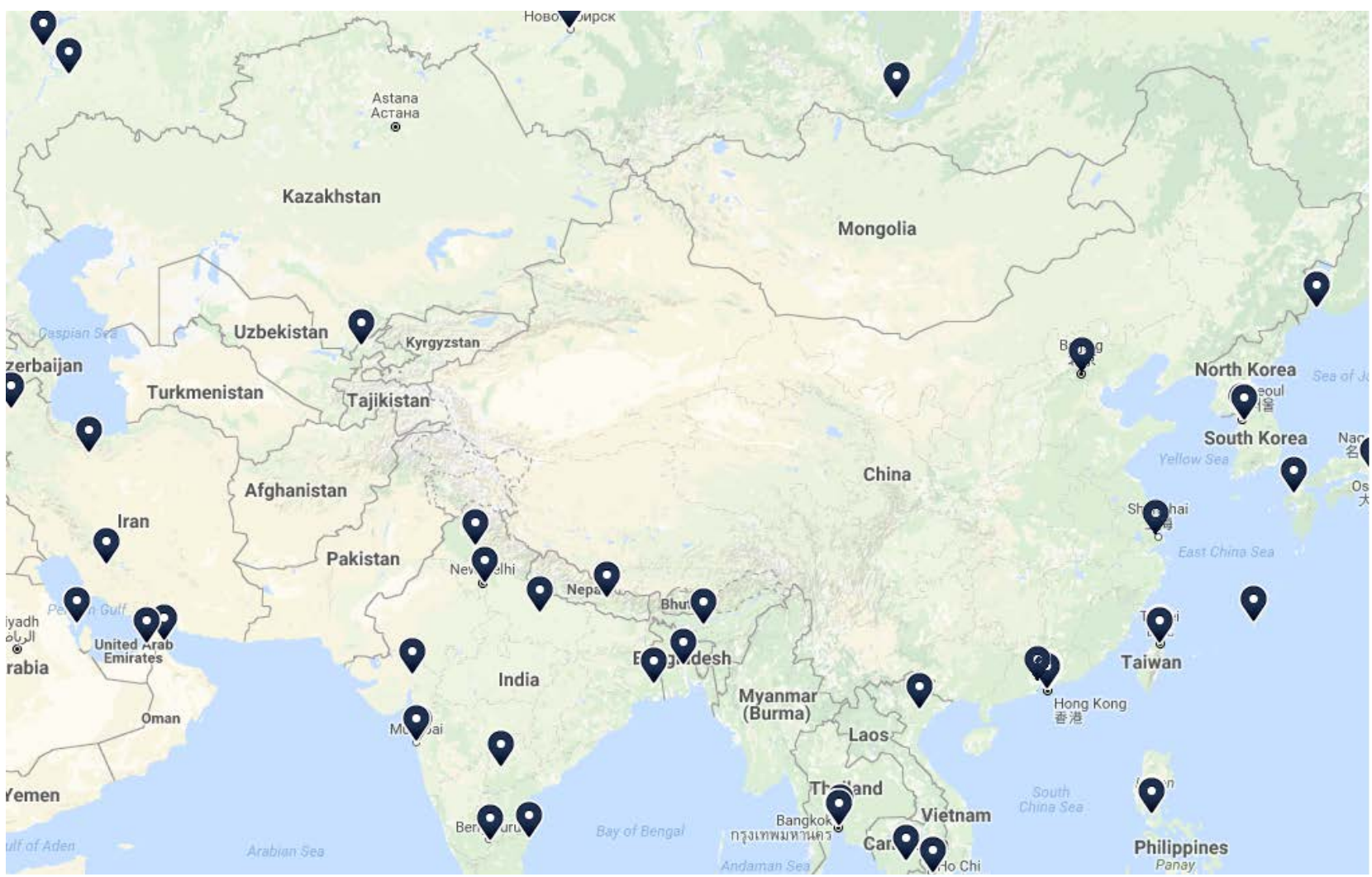

Figure 8. XPs in China and Central Asia

Source: Adapted from "TeleGeography Internet Exchange Map" 26

\section{Gap analysis}

The sources of growth exercise cover all 19 countries included in the descriptive analysis. To the best

\footnotetext{
${ }^{21}$ More information about carrier-neutral IXPs in China can be found at http://www.chn-ix.net.

${ }^{22}$ The details about IXP in Uzbekistan can be found at http://tas-ix.uz.

${ }^{23}$ The details about IXP in Kyrgyzstan can be found from "Kyrgyz Internet Environment Assessment" by ISOC.

${ }^{24}$ More information about IXPs in Asia and the Pacific can also be found at https://nsrc.org/ixp/AsiaPacific.html.

25 "Kyrgyz Internet Environment Assessment" by ISOC.

${ }^{26}$ Telegeography (2017). "Internet exchange map". Telegeography. Available from https://www.telegeography.com/telecom-resources/ internet-exchange- map/
} 
of our knowledge, this is the first attempt to provide an analysis of the sources of labour productivity growth that explicitly accounts for the contribution of tangible capital and an exhaustive list of intangible assets for so many European countries. The extended country coverage is not a free lunch. In fact, there is a trade-off between the number of countries and the number of years and variables that can be included in the analysis. Data availability does not allow us to account for the contribution of labour composition. Therefore, the measure of the residual component is the sum of the contributions of multi-factor productivity (MFP) and labour composition (LQ) to labour productivity growth. Moreover, we are not able to disentangle the contribution of tangible capital into ICT and non-ICT components. The analysis covers the period 2000-2013.

As discussed in Section 3, this study aims to perform a comparative analysis (gap analysis) on ICT connectivity in the China-Central Asia Corridor. "Gaps" in this study refer to the insufficiency or lacking capacity, process, policy and system in specific ICT areas which consequently cause these areas to work/function improperly or not up to expectations. Table 5 demonstrates some of the highlights of gap analysis in high priority areas based on the findings of the above analysis, taking into account the framework mentioned in Section 3. ${ }^{27}$

Table 5. Gap analysis in ICT area

\begin{tabular}{|c|c|c|}
\hline Area & Current State (As-Is) & Gap \\
\hline \multirow{3}{*}{ Capability } & $\begin{array}{l}\text { China and Central Asia can connect via three } \\
\text { cross-border fiber routes by using China- } \\
\text { Kazakhstan, China-Kyrgyzstan and China- } \\
\text { Tajikistan fiber routes. }\end{array}$ & $\begin{array}{l}\text { Redundant fiber route(s) is required: All three fiber- } \\
\text { optic routes provide connections from Central Asia to } \\
\text { China (and vice versa) via Urumqi regional international } \\
\text { gateway only. }\end{array}$ \\
\hline & $\begin{array}{l}\text { China and all countries in Central Asia can } \\
\text { access Internet and internationally connect to } \\
\text { other countries at various levels of international } \\
\text { bandwidth ranging from } 2.4 \text { Gbps in } \\
\text { Turkmenistan to } 5.39 \text { Tbps in China. However, } \\
\text { by focusing on Internet speed per user, the } \\
\text { country which has the maximum international } \\
\text { Internet bandwidth per Internet user is } \\
\text { Kazakhstan at } 51.49 \mathrm{Kbps} \text { and the minimum is } \\
1.29 \mathrm{Kbps} \text { in Uzbekistan, while the world } \\
\text { average is at } 61.82 \mathrm{Kbps} \text {. }\end{array}$ & $\begin{array}{l}\text { Inadequate international bandwidth: By focusing on } \\
\text { international Internet bandwidth per Internet user, every } \\
\text { country in this region has speed far below the world } \\
\text { average except Kazakhstan which has speed per Internet } \\
\text { user slightly below the world average at } 51.49 \mathrm{Kbps} \text {. } \\
\text { Tajikistan, Turkmenistan and Uzbekistan, which have } \\
\text { average international bandwidth per user lower than } 4 \\
\text { Kbps, could benefit from improvements. }\end{array}$ \\
\hline & $\begin{array}{l}\text { Every country in this region has various levels } \\
\text { of national fiber backbone networks to provide } \\
\text { connections among cities in each country. } \\
\text { Apart from infrastructure, both Internet } \\
\text { penetration and fixed broadband penetration in } \\
\text { Kyrgyzstan, Tajikistan and Turkmenistan are } \\
\text { below the global average (less than } 45.9 \text { per } \\
\text { cent in Internet penetration and less than } 12.4 \text { in } \\
\text { fixed broadband penetration). }\end{array}$ & $\begin{array}{l}\text { Inadequate national ICT infrastructure, including } \\
\text { domestic backbone networks, and low ICT penetration: } \\
\text { Low fiber density can also be found in other countries in } \\
\text { Central Asia, and this illustrates their lack of fiber route } \\
\text { redundancy in these parts of China and Central Asia. } \\
\text { Lack of broadband access is a main factor which } \\
\text { consequently causes low Internet penetration in Central } \\
\text { Asia, especially in Kyrgyzstan, Tajikistan and } \\
\text { Turkmenistan. This low ICT penetration consequently } \\
\text { affects socioeconomic activities at user level. }\end{array}$ \\
\hline
\end{tabular}

\footnotetext{
${ }^{27}$ For the comprehensive gap analysis results and emanating policy recommendations, refer to ESCAP (2017a).
} 
Table 5. Continued

\begin{tabular}{|c|c|c|}
\hline Area & Current State (As-Is) & Gap \\
\hline & $\begin{array}{l}\text { Asia. One indicator used to measure Internet } \\
\text { security is the number of secure server per } \\
\text { million people, which illustrates number of } \\
\text { servers utilizing encryption techniques to secure } \\
\text { their transactions. The world average is } 209 \\
\text { servers. However, the rate in this region is less } \\
\text { than } 18 \text { servers. }\end{array}$ & servers using encryption techniques. \\
\hline \multirow{3}{*}{$\begin{array}{c}\text { Implementation } \\
\text { and } \\
\text { Operation }\end{array}$} & $\begin{array}{l}\text { For fixed broadband pricing in terms of } \\
\text { percentage of GNI per capita, prices in China, } \\
\text { Turkmenistan and Uzbekistan are moderate at } \\
3.58,4.3 \text { and } 4.73 \text { per cent, respectively, and } \\
\text { prices in Kyrgyzstan are expensive at } 10.66 \text { per } \\
\text { cent. } \\
\text { Mobile broadband prices are moderate in in } \\
\text { Tajikistan, Kyrgyzstan and Turkmenistan (for } \\
\text { both postpaid and prepaid with } 1 \mathrm{~GB} \text { ) at } 9.8- \\
16.44 \text { per cent. Prices are at about } 28.75 \text { per } \\
\text { cent of GNI per capita in Uzbekistan, which is } \\
\text { considered unaffordable. }\end{array}$ & $\begin{array}{l}\text { High broadband pricing: Broadband pricing is another } \\
\text { factor that directly affects ICT penetration. If they are } \\
\text { too expensive or unaffordable, people cannot afford to } \\
\text { access broadband networks affecting usage and demand } \\
\text { for services. Policy and regulatory considerations could } \\
\text { be effective in addressing the challenges of affordability } \\
\text { in this regard. }\end{array}$ \\
\hline & $\begin{array}{l}\text { The main fiber routes, such as Trans Asia- } \\
\text { Europe (TAE) and cross-border fiber routes, are } \\
\text { typically managed by different national service } \\
\text { providers. For example, the TAE route in } \\
\text { Central Asia is operated and managed by } \\
\text { Kazakh telecom, Kyrgyz telecom and Turkmen } \\
\text { telecom. }\end{array}$ & $\begin{array}{l}\text { Building Quality of Service (QoS) between endpoints } \\
\text { comes with high transit costs, because fiber routes are } \\
\text { operated differently by multiple operators for } \\
\text { Operations, Administration and Maintenance (OAM). It } \\
\text { is also challenging to build in uniform quality of } \\
\text { services between endpoints to guarantee traffic delivery, } \\
\text { which additionally incurs high transit costs. Moreover, } \\
\text { ICT infrastructure including backbone networks must } \\
\text { aim for seamless integration for effective synergy and } \\
\text { collaboration. }\end{array}$ \\
\hline & $\begin{array}{l}\text { The main fiber route that links together China } \\
\text { and countries in Central Asia is TAE. The } \\
\text { technology used in this route as well as cross- } \\
\text { border routes among them is Synchronous } \\
\text { Digital Hierarchy (SDH). }\end{array}$ & $\begin{array}{l}\text { Outdated WAN transport technology and High OPEX: } \\
\text { SDH is the main transport technology used in TAE and } \\
\text { cross-border fiber routes. This pure SDH technology is } \\
\text { said to be reliable. However, it is a legacy technology } \\
\text { and initially designed to support voice services. In } \\
\text { addition, it is very complex and incurs higher OPEX } \\
\text { compared to other technologies such as Optical } \\
\text { Transport Network (OTN), Dense Wavelength Division } \\
\text { Multiplexing (DWDM) and Multiprotocol Label } \\
\text { Switching - Transport Profile (MPLS-TP). }\end{array}$ \\
\hline
\end{tabular}

\subsection{Challenges and issues}

In the previous section, the inefficiency and/or missing factors are presented in terms of gaps. There is a relationship between gaps and challenges/issues. If unaddressed, the gaps will remain or exacerbate, eventually leading to negative impacts on I CT connectivity. Here, the template for challenge characterization recommended by the UN Public Administration Network (UNPAN) is also adopted to 
summarize challenges, issues and barriers found via conducting a gap analysis. Table 6 lists some of the challenges and the issues that can impact ICT connectivity in China and Central Asia. ${ }^{28}$

In order to estimate the severity of ICT challenges based on possible impact, three categories are used in this article: high, medium and low. If challenges or issues are likely to cause serious negative effects, if unaddressed, they are assigned to "high". If problems cause minor impacts (i.e., can still operate with some effects), they are assigned to the medium impact category. If the challenges or issues cause no effect (or possibly small effects) on ICT connectivity when they are not solved, they are classified as minimal impact.

Table 6. Challenges and issues

\begin{tabular}{|c|c|c|}
\hline Area & Challenge and Issue & Impact \\
\hline \multirow{3}{*}{ Capability } & $\begin{array}{l}\text { Redundant fiber route(s) is required. For example, in connections between China } \\
\text { and Central Asia, redundant route to another China regional international gateway } \\
\text { (apart from Urumqi node) is recommended to guarantee high availability } \\
\text { connections among China and other countries. }\end{array}$ & High \\
\hline & $\begin{array}{l}\text { More international bandwidth and the increase in speed per Internet user must be } \\
\text { considered. }\end{array}$ & High \\
\hline & $\begin{array}{l}\text { National ICT infrastructure including domestic backbone networks is required to } \\
\text { increase capacity and service coverage. }\end{array}$ & High \\
\hline Security & $\begin{array}{l}\text { Security in ICT infrastructure is required to guarantee secured connections and } \\
\text { operations. }\end{array}$ & High \\
\hline \multirow{7}{*}{$\begin{array}{l}\text { Implementation and } \\
\text { Operation }\end{array}$} & $\begin{array}{l}\text { Network topology is not scalable; new network topology redesign (in terms of } \\
\text { arrangement of nodes and their connections) is required to build hierarchical } \\
\text { network topology to support network scalability. }\end{array}$ & Medium \\
\hline & Broadband prices must be reduced to be affordable by people in Central Asia. & High \\
\hline & $\begin{array}{l}\text { Carrier-neutral IXPs are required to be implemented in Central Asia to prevent } \\
\text { unnecessary local traffic transited across international links. }\end{array}$ & Medium \\
\hline & $\begin{array}{l}\text { International cooperation or policy coordination among countries along the Belt and } \\
\text { is required for effective implementation. }\end{array}$ & High \\
\hline & $\begin{array}{l}\text { More cost-efficient and effective WAN transport technologies (OTN, DWDM, etc.) } \\
\text { must be considered for international fiber routes to directly improve Operation, } \\
\text { Administration and Maintenance (OAM) to reduce OPEX. }\end{array}$ & High \\
\hline & $\begin{array}{l}\text { ICT infrastructure must be open and standardized to simplify seamless network } \\
\text { integration. }\end{array}$ & Medium \\
\hline & $\begin{array}{l}\text { Cross-sectoral infrastructure synergies are required to accelerate and support } \\
\text { connectivity among countries along the Belt and Road. }\end{array}$ & Medium \\
\hline
\end{tabular}

${ }^{28}$ The comprehensive list is available in the ESCAP BRI report (ESCAP, 2017a). 


\section{Proposed resilient network topology}

Based on the gap analysis and challenges identified, this study aims to design and recommend a network topology by c omparing major cities' geographical location, intra-corridor connectivity and international connectivity criteria. It identifies a hybrid network with new nodes proposed to ensure efficient ICT connectivity along the China-Central Asia Corridor.

The design of network topology and IXPs in China and Central Asia needs to ensure that ICT connectivity in this Corridor effectively links to other regions such as West Asia and South Asia. Thus, ICT connectivity to five more countries is also proposed in this design, which includes Afghanistan, Azerbaijan, Iran, Pakistan and Turkey.

The scoring method for node selection criteria (geographical location, intra-corridor connectivity and international connectivity) is set as follows: geographical location (4 points) and intra-corridor connectivity and international connectivity ( 3 points for each criterion), with a total maximum score of 10 points. More weight is given to geographical location, since core nodes must be easily accessed by other countries for intra-and inter-corridor connectivity. An equal lower weight is given to intra-corridor connectivity and international connectivity, due to the fact that the main responsibility of core nodes is to provide connections to other country nodes (both core and access nodes). Table 7 summarizes the assessment results.

Table 7. Core node selection criteria

\begin{tabular}{|c|c|c|c|c|}
\hline Gateway & $\begin{array}{c}\text { Geographical Location } \\
\mathbf{( 0 - 4 )}\end{array}$ & $\begin{array}{c}\text { Intra-corridor } \\
\text { Connectivity (0-3) }\end{array}$ & $\begin{array}{c}\text { International Connectivity } \\
\mathbf{( 0 - 3 )}\end{array}$ & $\begin{array}{c}\text { Total Score } \\
\mathbf{( 0 - 1 0 )}\end{array}$ \\
\hline $\begin{array}{c}\text { Urumqi, Xinjiang, } \\
\text { China }\end{array}$ & 4.0 & 2.5 & 3.0 & 9.5 \\
\hline Kazakhstan & 3.5 & 2.5 & 3.0 & 9.0 \\
\hline Kyrgyzstan & 2.5 & 2.5 & 2.0 & 7.0 \\
\hline Tajikistan & 3.0 & 2.5 & 2.5 & 8.0 \\
\hline Turkmenistan & 3.0 & 2.5 & 2.5 & 8.0 \\
\hline Uzbekistan & 3.0 & 2.5 & 2.5 & 8.0 \\
\hline
\end{tabular}

To successfully implement this Corridor connecting countries along the Belt and Road, Kazakhstan and Urumqi have been selected to be the core nodes for both intra- and inter-Corridor connectivity, while the other nodes are assigned as access nodes and can possibly reach other countries (in other regions/corridors) via core nodes as illustrated in Figure 9. 


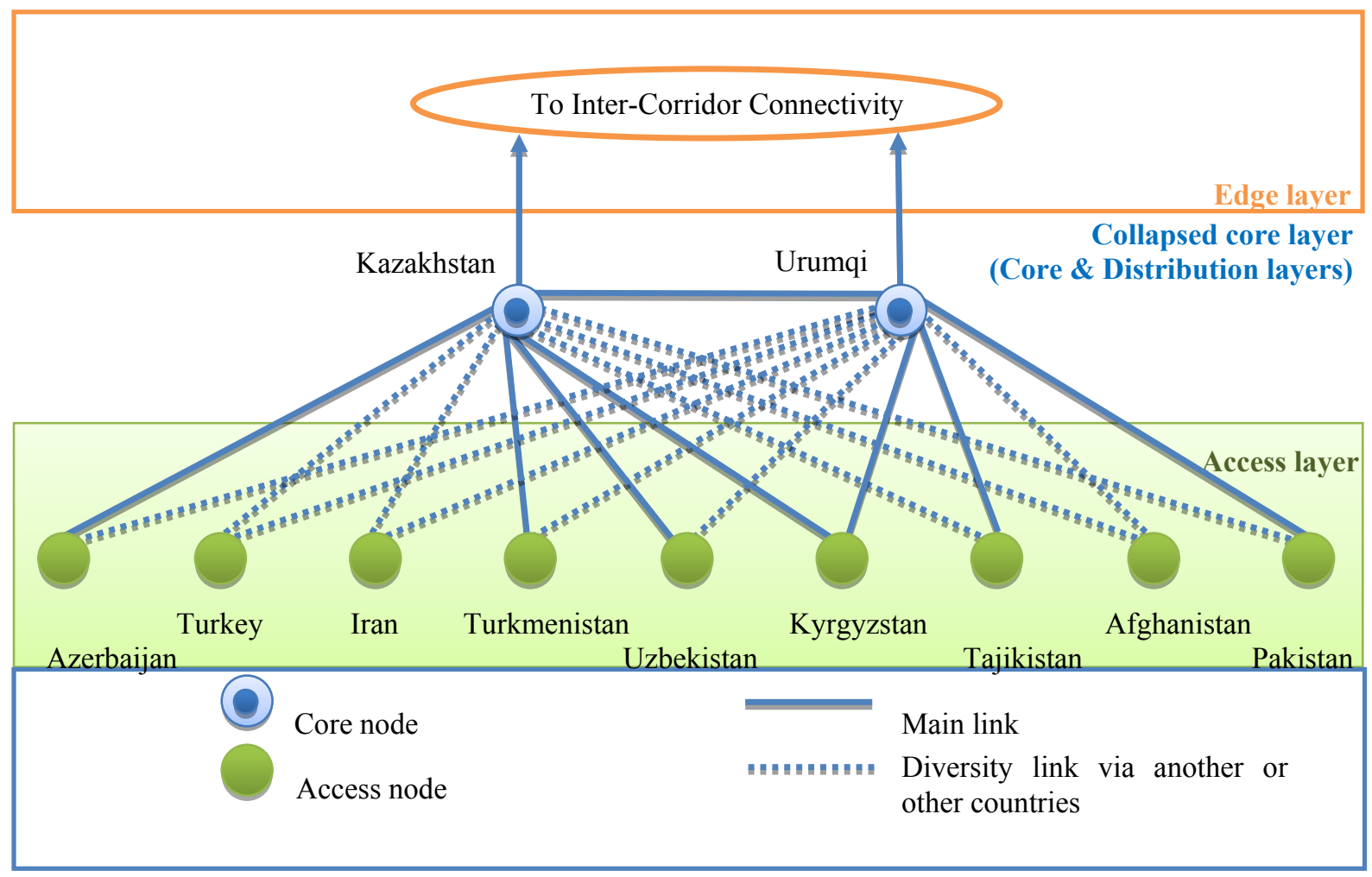

Figure 9. Logical network topology in China-Central Asia corridor

Once nodes including core and access nodes are chosen, the connections among them are required in order to implement regional or global IXPs (interconnection of IXPs among countries). The process of determining how they are logically or physically connected is referred to as topology selection and design, which is described in Table 8 .

Table 8. Network topology selection criteria

\begin{tabular}{|c|c|c|c|c|c|c|}
\hline Topology & $\begin{array}{c}\text { Performance } \\
\mathbf{( 0 - 2 )}\end{array}$ & $\begin{array}{c}\text { Redundancy } \\
\mathbf{( 0 - 2 )}\end{array}$ & $\begin{array}{c}\text { Scalability } \\
\mathbf{( 0 - 2 )}\end{array}$ & $\begin{array}{c}\text { Complexity } \\
\mathbf{( 0 - 2 )}\end{array}$ & $\begin{array}{c}\text { Cost } \\
\mathbf{( 0 - 2 )}\end{array}$ & $\begin{array}{c}\text { Total Score } \\
\mathbf{( 0 - 1 0 )}\end{array}$ \\
\hline Star & 1.5 & 0.5 & 1.5 & 2.0 & 1.5 & 7.0 \\
\hline Ring & 1.5 & 2.0 & 1.5 & 1.5 & 2.0 & 8.5 \\
\hline Full Mesh & 2.0 & 2.0 & 1.5 & 1.0 & 0.5 & 7.0 \\
\hline Partial Mesh & 2.0 & 2.0 & 2.0 & 1.5 & 1.5 & 9.0 \\
\hline
\end{tabular}

By comparing all topologies, partial mesh has the highest score, and it is the most appropriate topology to be used to form a hierarchical model in regional (or global) IXPs in the China-Central Asia Corridor. 
Because of a shorter path in the two-tier hierarchical network model, traffic delivery is very efficient, while resilience is also achieved because of redundant link(s). Therefore, partial mesh is recommended in this study. Given the criteria, partial mesh topology offers many advantages in terms of performance, redundancy and scalability and it is consequently chosen to connect multiple nodes together to form a regional (or global) IXP in the China-Central Asia corridor. Note that logical topology normally illustrates how each node logically communicates with the others.

Note that to effectively support ICT connectivity in this corridor, ICT connectivity to five more countries is also proposed, which are Afghanistan, Azerbaijan, Iran, Pakistan and Turkey. The hierarchical network model is applied instead of the flat network model to achieve scalability. There are two layers/tiers in this topology: collapsed core layer (combination of core and distribution layers) and access layer. Core nodes typically provide backbone connection to both inter-corridor and intra-corridor connectivity. In this proposed topology, Kazakhstan and Urumqi are selected to be the core nodes because of their strong international connectivity, while the others are dynamically classified as the access nodes, as illustrated in Figure 10.

In addition, each access node has at least two fiber-optic routes to two different core nodes using both main route and/or diversity route(s) via other countries (a diversity route is used in case that the access nodes do not share the direct border with core nodes) to achieve resilience. Hence, in the case that one node is experiencing outage, this does not affect the others because they can use redundant route(s) to directly access this network.

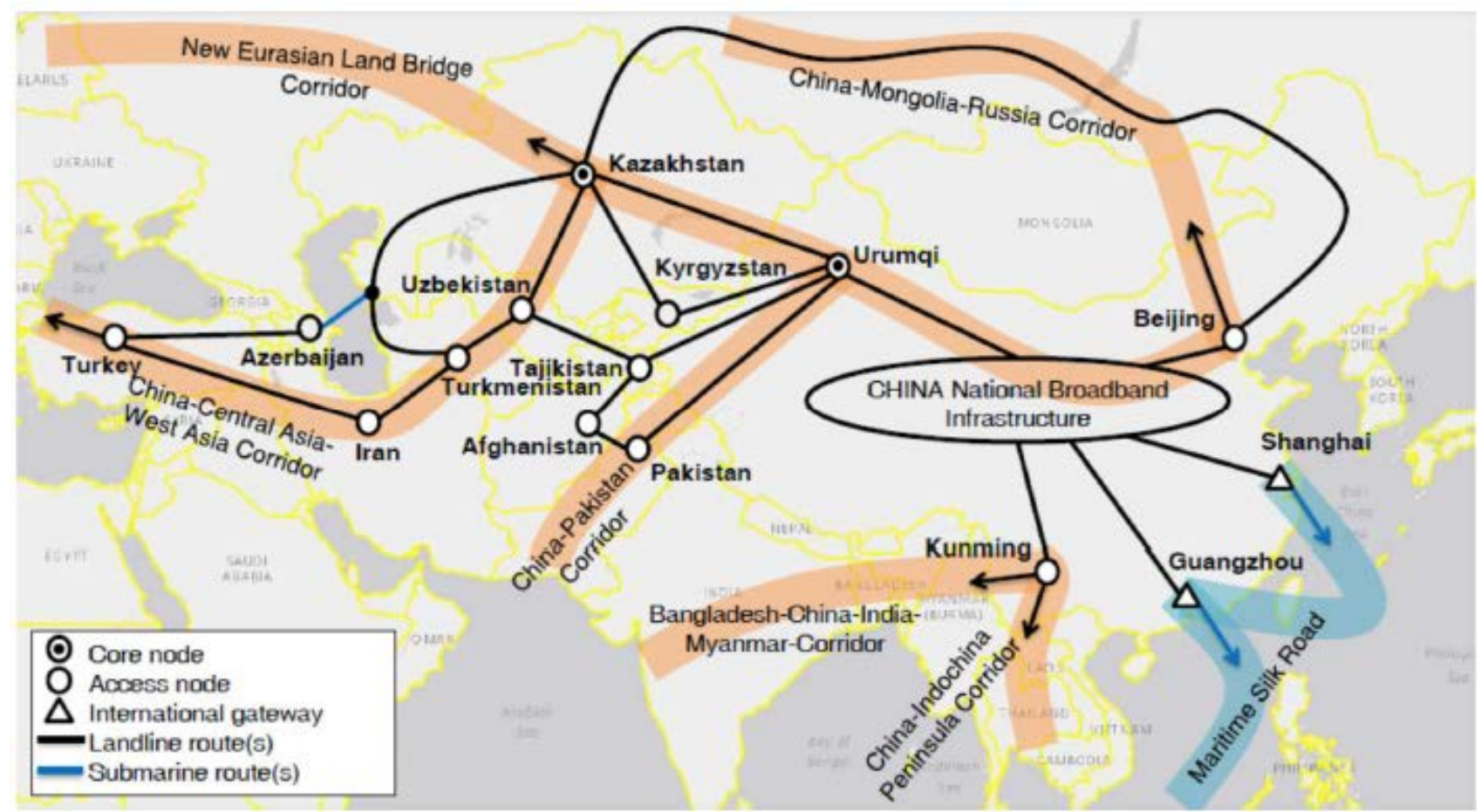

Figure 10. Physical network topology of intra- and inter-corridor connectivity

Source: "A Study of ICT Connectivity for the Belt and Road Initiative (BRI): Enhancing the Collaboration in China-Central Asia Corridor" produced by ESCAP, p. $61(2017 a)$ 


\section{Policy implications and the way forward}

The main challenges identified by the study can be summarized as follows:

(1) Redundant fiber route is required: China and Central Asia could enhance ICT connectivity through connection via proposed cross-border fiber routes.

(2) More international bandwidth is required: Tajikistan, Turkmenistan and Uzbekistan have an average international bandwidth per user lower than 4 kbps.

(3) National ICT infrastructure (domestic backbone networks) is required: China has low fiber connectivity density in central and western areas. Kyrgyzstan, Tajikistan and Turkmenistan are far below the global average fixed broadband penetration.

(4) Security in ICT infrastructure is required to improve secured connections: Encryption techniques are adopted in a small number of servers. The average number of secure servers in this region is less than 18 whereas the world average is 209 .

(5) Broadband prices must be reduced to be affordable: Broadband price in terms of percentage of GNI per capita is more than 5 per cent in some countries.

(6) International cooperation or policy coordination among countries is required for the effective implementation and operation of networks: Since networks are often operated by multiple operators, there is difficulty and complexity in building uniform quality of services between endpoints to guarantee traffic delivery and ensure low transit cost.

The China-Central Asia Corridor needs more support in the number and capacity of new ICT connectivity initiatives as well as the need for increased affordability. Considering the above challenges, the study proposed Kazakhstan and Urumqi to be the core nodes for both intra- and inter-corridor connectivity among each economic corridor, while the other nodes are access nodes and can possibly reach other countries (in other regions/corridors) via core nodes.

The proposed topology aims at increasing redundancy and resilient terrestrial fiber-optic connectivity and efficient traffic flow between countries along the corridor. Some of the associated recommendations in implementing the proposal in particular and infrastructure development in general include codeployment of multiple infrastructures with the aim of reducing investment and maintenance costs, closing the digital divide and advancing digital economy initiatives such as trade and transport facilitation's "paperless trade" and e-commerce.

As a viable avenue to achieve the above objectives and enhance regional cooperation, various connectivity initiatives and platforms, such as the Asia-Pacific Information Superhighway (AP-IS), were developed. It aims to improve regional broadband connectivity through a dense web of cross-border infrastructure and promote open access to ICT infrastructure for the ultimate purpose of increasing coverage, availability, reliability and affordability. At its core is the creation of a seamless regional network of fiber-optic cables to provide both intra-regional and intercontinental connectivity. Furthermore, AP-IS supports cross-sectoral synergies with transport, energy and trade under overall objective of promoting regional economic connectivity and facilitating the movement of people, goods, information, knowledge and money. The AP-IS initiative aims to create synergies with regional and subregional connectivity initiatives, including BRI, TASIM, GMS Information Superhighway and ASEAN connectivity initiatives. The cooperation through analytical and technical studies between initiatives 
would reduce duplications and create synergies for the ultimate objectives of achieving seamless connectivity.

Through enhanced regional and national connectivity and improved broadband access among people in the region, it is expected that ICT contributes directly and indirectly to economic, social and environmental aspects of Sustainable Development Goals (SDG). Specific SDG targets and goals include Target 9.1 ("Develop quality reliable, sustainable and resilient infrastructure, including regional and transborder infrastructure, to support economic development and human well-being, with a focus on affordable and equitable access for all") and Target 9.c ("Significantly increase access to ICT and strive to provide universal and affordable access to the Internet in least developed countries by 2020 "). Furthermore, under Goal 4 on education, one target requires the member countries to expand educational opportunities in ICT. ${ }^{29}$ In the area of gender equality, Goal 5 has the target of "enhance the use of enabling technology, information and communications technology, to promote the empowerment of women." A goal under SDG 17 further specifies the role of ICT as a m eans of implementation. ${ }^{30}$ The proposed regional connectivity and networks will pave the way for the regional's digital transformation and inclusive sustainable development.

\section{Limitations}

As a way forward, limitations encountered in the analysis of this research are important to highlight for future research. Limited primary information on I nternet traffic and network management in several countries of the China-Central Asia Corridor hindered complete cross-country comparison. As a result, analysis was dependent on secondary sources from online government websites, reports on ICT policies and regulations, and online media releases. Follow-up studies may need to undertake primary data collection in order to triangulate the proposed findings in this study. It is also important to note that based on the methodology used and the information collected, the key policy recommendations of this study may differ from others in approach and data used. Further, technologies evolve very quickly and thus the policy recommendations of today may risk being obsolete in one or two year's time. Lastly, the scope of the original report was focused on the China-Central Asia Corridor which was partly funded by the Government of People's Republic of China.

\section{References}

Asian Development Bank (2015). Regional: Digital Economy Study in Central and West Asia (Unleashing the potential of the Internet in Central Asia, South Asia, the Caucasus and beyond). Manila, the Philippines: Asian Development Bank.

(2016). Road to 2030: Information and Communications Technology in ADB's corporate strategy and operations. Manila, the Philippines: Asian Development Bank.

\footnotetext{
29 "By 2020, substantially expand globally the number of scholarships available to developing countries, least developed countries, small island developing States and African countries, for enrolment in higher education, including vocational training and information and communications technology, technical, engineering and scientific programmers, in developed countries and other developing countries."

30 "Fully operationalize the technology bank and science, technology and innovation capacity-building mechanism for 1 east developed countries by 2017 and enhance the use of enabling technology, information and communications technology."
} 
(2017). Meeting Asia's Infrastructure Needs. Manila, the Philippines: Asian Development Bank. doi: 10.22617/FLS168388-2.

Bolger N (2016). Omantel and Multinet Pakistan Announce Silk Route Gateway. May 10, 2016. London, UK: Capacity Media.

CNNIC (2016). Statistical Report on Internet Development in China. Beijing, China: CNNIC.

Electronic Government of the Republic of Kazakhstan (2017). Informational Kazakhstan-2020. State Program. Kazakhstan: Electronic Government of the Republic of Kazakhstan.

ESCAP (2014). An In-Depth Study of Broadband Infrastructure in North and Central Asia. Bangkok, Thailand: ESCAP. (2016a). Building E-resilience in China: Enhancing the Role of Information and Communications Technology for Disaster Risk Management. Bangkok, Thailand: ESCAP.

(2016b). Updated Analysis of the Broadband Infrastructure in the ESCAP Region. Bangkok, Thailand: ESCAP. (2017a). A Study of ICT Connectivity for the Belt and Road Initiative (BRI): Enhancing the Collaboration in China-Central Asia Corridor. Bangkok, Thailand: ESCAP.

(2017b). "Trade and trade facilitation along the belt and road initiative corridors". ARTNeT Working Paper Series No. 172. Bangkok, Thailand: ESCAP.

(2017c). Artificial Intelligence and Broadband Divide: State of ICT Connectivity in Asia and the Pacific 2017. Bangkok, Thailand: ESCAP. (2017d). Effect of Open International Gateways on the Broadband Connectivity Market. Bangkok, Thailand: ESCAP. (2017e). Building a Resilient Digital Economy: Fostering Smes in Central Asia. Bangkok, Thailand: ESCAP. (2017f). The Impact of Universal Service Funds on Fixed-Broadband Deployment and Internet Adoption in Asia and the Pacific. Bangkok, Thailand: ESCAP.

ESCAP (2017g). Enhancing Regional Economic Cooperation and Integration in Asia and the Pacific. Bangkok, Thailand: ESCAP.

Government of the Republic of Tajikistan (2009). "Development of ICT in the Republic of Tajikistan". Presentation during the Sub-regional Workshop on Strengthening ICT Policies and Applications to Achieve MDGs and WSIS Goals in Central Asia and South Asia, October 21-22, 2009. Bangkok, Thailand: ESCAP.

Inderst G (2016). "Infrastructure investment, private finance and institutional investors: Asia from a global perspective". ADBI Working Paper Series, No. 555. Tokyo, Japan: Asian Development Bank Institute. doi: $10.2139 /$ ssrn. 2721577 .

ISOC (2015). Internet Exchange Points (IXPs). Reston, VA, USA: ISOC.

ITU (2017a). Measuring the Information Society Report 2017. Geneva, Switzerland: International Telecommunication Union. 
(2017b). ICT Facts and Figures. Geneva, Switzerland: International Telecommunication Union.

McKinsey Global Institute (2016). Bridging Global Infrastructure Gaps. Shanghai, China. McKinsey \& Company

Ministry of Industry and Information Technology (MIIT) of the People's Republic of China (2016). "Broadband China strategy and its implementation". Presentation during Workshop on Knowledge and Policy Gaps in Disaster Risk Reduction and Development Planning, March 8-9, 2016. Bangkok, Thailand: ESCAP.

National Development and Reform Commission (NDRC) (2015). Vision and actions on jointly building Silk Road Economic Belt and 21st-Century Maritime Silk Road. Beijing, China: The National Development and Reform Commission of the People's Republic of China.

National Council for Sustainable Development of the Kyrgyz Republic (2015). National Sustainable Development Strategy for the Kyrgyz Republic for the Period of 2013-2017. Bishkek City, Kyrgyz Republic: National Statistical Committee of the Kyrgyz Republic.

TeleGeography (2016). Cable Compendium: A Guide to the Week'S Submarine and Terrestrial Developments. July 15, 2016. Washington, DC, USA: TeleGeography. (2017). Cable Compendium: A Guide to the Week's Submarine and Terrestrial Developments. January 13, 2017. Washington, DC, USA: TeleGeography.

Times of Oman (2016). "Omantel Connects Africa to Asia with Subsea Cable Systems". November 1, 2016. Muscat, Oman: Times of Oman.

World Bank (2014). World Development Indicators: The Information Society. Washington, DC, USA: World Bank.

World Bank (2015). World Development Indicators 2015. Washington, DC, USA: World Bank. doi: 10.1596/978-14648-0440-3.

World Bank (2017). World Development Indicators 2017. Washington, DC, USA: World Bank. 